DOI: 10.31548/machenergy.2019.01.049-055

UDC 656.073.28-043.2(477)

\title{
MAIN FACTORS THAT HAVE IMPACT ON UKRAINIAN MARKET OF TRANSPORT SERVICES
}

\author{
O. M. Zagursky, B. S. Marchenko
}

National University of Life and Environmental Sciences of Ukraine, Ukraine.

Corresponding authors: zagurskiy_oleg@ukr.net.

Article history: Received: March 2019. Received in the revised form: April 2019. Accepted: June 2019.

Bibl. 8, fig. 7, tabl. 1.

Abstract. The state of the freight transport market in Ukraine depends on three main factors: foreign trade turnover, gross domestic product and production. When all these indicators grow, logistics also develops, and along with it along the ascending line rises transport.

The article analyzes the main factors influencing the level of competitiveness of economic entities in the market of transport services in Ukraine.

The main criteria, which ensure the sustainable development of the market of motor transport services is defined: geographic position; the dynamics of the situation of the sector commodity markets; the level of demand and supply in the market of transport services; dynamics of market conditions of motor transport freight transportation; state and competitive environment in the middle of the industry.

Results of the conducted analytical research for 2014-2018, the market of transport services of Ukraine certify that the motor transport industry having experienced the same losses during the crisis period as in the whole of Ukraine The fastest pace goes out of her and the share of road transport in the volumes of cargo transportation every year increases.

Key words: motor transport, competitiveness, demand, supply, market of transport services.

\section{Introduction}

The market for motor transport services is what it has. function in this way. not only to promote the promotion of goods from manufacturers. to consumers, but also fully satisfy the requirements of customers. (shippers and consignees) in the shortest possible time. and with the least cost of resources. The most important factors in assessing the quality of its services are:. time of order fulfillment; completeness, degree of accessibility. and reliability of the order fulfillment; objectivity of tariffs. and the regularity of the information about the location of the cargo.

\section{Formulation of problem}

The peculiarity of the market for motor transport services is that it should function in such a way as to not only facilitate the promotion of goods from the manufacturer to the consumers, but also fully satisfy the requirements of customers (shippers and consignees) in the shortest possible time and with the least cost of resources. The most important factors in assessing the quality of its services are: the time of execution of the order; completeness, degree of availability and reliability of the order fulfillment; the objectivity of the tariffs and the regularity of the information on the location of the goods.

\section{Analysis of recent research results}

Some aspects of this problem reflected in the writings J. Allen, M. Broun, T. Cherret [7], V. Zamlynsky, V. Koval, V. Kotlubay [3], O. Parubets [4], P. Popovich, O. Shevchuk, A. Matviishin, V. Lototskaya [6],

However, under the condition of the development of globalization processes, informatization of society, increase in freight traffic directly depends on effective development. the market of transport services and its infrastructure, which requires conducting further research in this direction.

\section{Purpose of research}

The purpose of the work is analytical research of the main factors of influence on the level of competitiveness business entities in the market of transport services in Ukraine.

\section{Results of research}

On the structure market of motor transport services are influenced by three groups of factors related to globalization trends and interbranch and intra-industry factors of economic development.

The first group includes indicators that related to liberalization. trade and economic relations, from the simplification of international trade. by reducing domestic tariffs, up to the complete elimination of customs barriers in mutual trade. Globalization of 
markets and integration at the mega-level and accordingly the emergence of transnational companies. (TNCs), generally eliminate, or significantly reduce competition between business entities.

The second group are the macroeconomic factors of national economy, quantitative and qualitative indicators of the level of demand on transport services of branches of the national economy. They directly influence the level of consumer activity - economic agents and households.

The third set of indicators is a set of indicators that characterize the level of satisfaction manufacturers of goods and services available on the market transport services and conditions of interaction subjects of the market.

The state of the market segment of motor transport services should be evaluated according to the following criteria:

- geographical location;

- the dynamics of the situation of sector commodity markets;

- the level of demand and supply in the market of transport services;

- the dynamics of the market conditions for road freight transportation;

- condition and competitive environment in the middle of the industry.

Let's consider them in more detail:

Geographical location. Favorable geographical position. makes Ukraine an important transport hub. connecting Europe, Asia and the Middle East. Road network of Ukraine. covering the entire territory of the country, it makes it possible to deliver the goods to any destination.

The territory of Ukraine includes 5 international transport corridors.

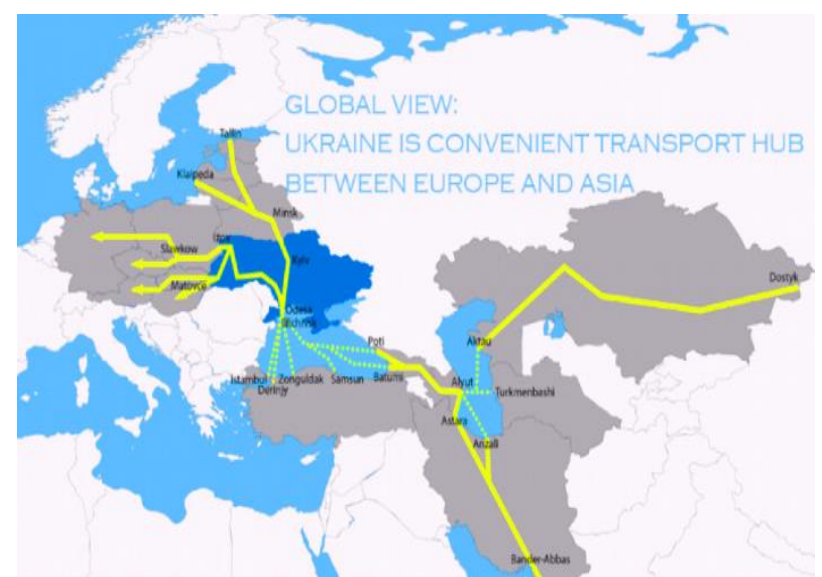

Fig. 1. Scheme of international transport corridors passing through the territory of Ukraine.

Source:https://mtu.gov.ua/content/tmu.html.

With a total length of more than $5000 \mathrm{~km}$, namely:

- Pan-European Transport Corridor No. 3 (passing through Germany, Poland and Ukraine along the route Dresden - Wroclaw - Lviv - Kiev Length - 1,640 km, of which, through which through Ukraine pass $694 \mathrm{~km}$ of railways and $611 \mathrm{~km}$ of highways);

- Pan-European Transport Corridor No. 5 (passing through Italy, Slovenia, Hungary, Slovakia and Ukraine, it connects Venice and Kiev via Ljubljana, Budapest and Uzhhorod, with a length of $1,595 \mathrm{~km}$, of which $339 \mathrm{~km}$ of railways pass through Ukraine and $266 \mathrm{~km}$ of highways);

- Pan-European Transport Corridor No. 7 (connecting Austria, Hungary, Bulgaria, Romania, Moldova and Ukraine: $70 \mathrm{~km}$ of this corridor passes through Ukraine);

- Pan-European Transport Corridor No. 9 (passes through Finland, Russia, Ukraine, Belarus, Moldova, Romania, Greece.) This corridor connects Helsinki - St. Petersburg - Gomel - Kiev - Odessa - Bucharest Alexandroupolis, length - 3,400 km, of which 1,496 km of railways and $996 \mathrm{~km}$ of roads pass through the territory of Ukraine);

- The international transport corridor GdanskOdessa (passing through Italy, Slovenia, Hungary, Slovakia and Ukraine, joining Trieste - Ljubljana Budapest - Bratislava - Uzhhorod - Lviv, length $1,816 \mathrm{~km}$, of which $266 \mathrm{~km}$ of railway pass through the territory of Ukraine roads and $338.7 \mathrm{~km}$ of highways)

Dynamics of the situation of sector commodity markets. In Ukraine, the commodity-producing sectors of the economy include coal, metallurgy and chemical industry, construction industry, and agriculture. Products of plant cultivation, in particular cereal crops, are the most dynamically growing cargo base in recent years.

Analysis of foreign trade of the country. over the last five years (Fig. 2) testifies to. its substantial decrease in 2014-2016. in comparison with the previous ones (linked both to the global financial and economic crisis and to the systemic economic and political crises in the country, and especially to russian aggression).

Another after 2009, the fall of industrial production in 2015 (approximately 13.4\%) was triggered primarily by a reduction in external demand for goods and services and a decrease in foreign direct investment. Only in 2017 begins a slight increase in cargo turnover, production of industrial products, which continued throughout 2018.

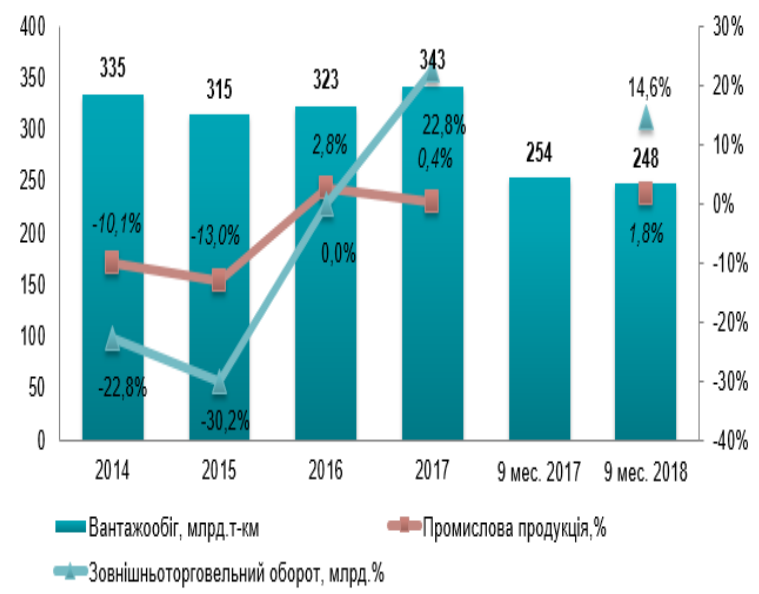

Fig. 2. Dynamics of cargo turnover, production of industrial products in 2014-2018.

Source: Data of the State Statistics Service of Ukraine for the relevant years.

Source: data of the State Statistics Service of Ukraine for the relevant years. 
As for domestic trade in the country, it should be noted that its state is much better. Volumes of wholesale trade turnover (Figure 3) are constantly increasing (growth rates make up 32\% in 2016 and $22.7 \%$ in 2017 compared to previous years). And in the first half of 2018, the wholesale turnover exceeded a trillion hryvnas, which would approximate it to the figure of 2015.

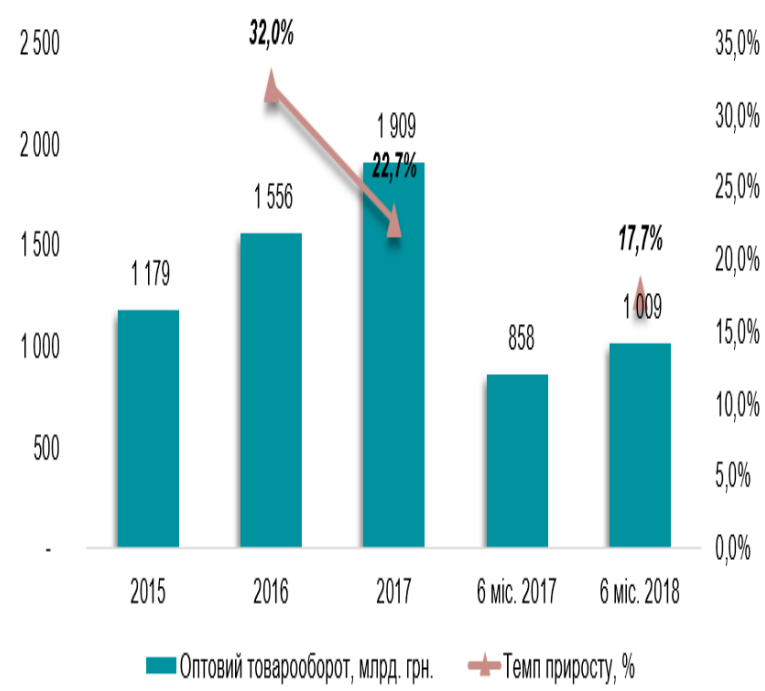

Fig. 3. Dynamics of the volume of wholesale trade turnover in Ukraine for 2015-2018.

Source: Data of the State Statistics Service of Ukraine for the relevant years.

Regarding the volumes of retail trade, they, despite the significant decrease in purchasing power of the population, are also growing (Fig. 4). And if during 2014-2015 there was a decrease in physical volumes of retail trade turnover $-90.0 \%$ and $80.2 \%$ respectively. In 2016, the growth of retail trade turnover in Ukraine amounted to $16.3 \%$, in $2017-5.5 \%$, and according to the results of the first half of 2018 , its growth rate increased to $18.8 \%$ over the same period last year.

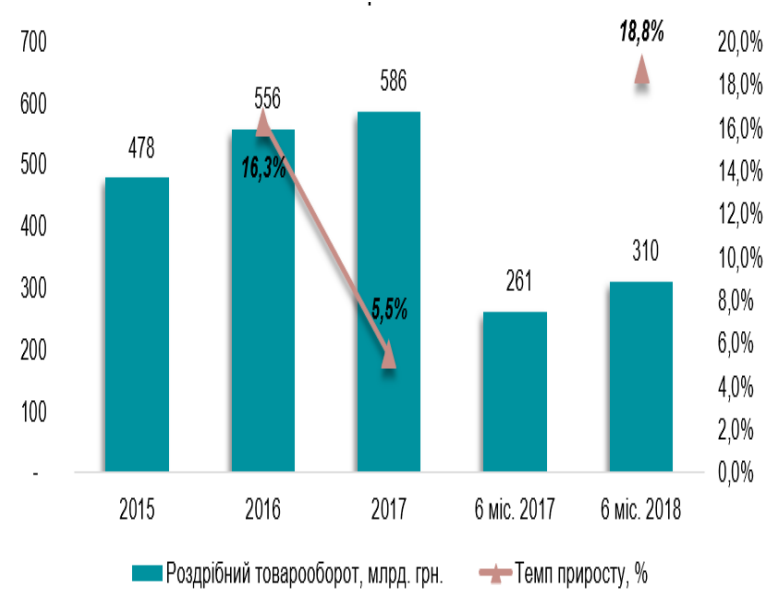

Fig. 4. Dynamics of Retail Turnover in Ukraine 2015-2018.

Source: Data from the State Statistics Service of Ukraine for the relevant years.

At the same time, noting some positive tendencies of increasing retail trade turnover, it should be noted that the significant contribution to the growth of the actual retail turnover in the analyzed period was created due to the extensive factor, namely, the rapid growth of prices for consumer goods. Thus, the consumer price index in 2014 in relation to 2013 was $124.9 \%$, in $2015-143.3 \%$, in $2016-112.4 \%$, in $2017-113.7 \%$, in $2018-109,8$ with similar comparisons.

The level of demand and supply in the market of transport services.

Analyzing the dynamics of the freight transport market, we note that the sharp decline in the country's external commodity turnover in 2014 , and, accordingly, the volumes of cargo transportation in subsequent years by $9-18 \%$, and the freight turnover of $9-15 \%$ compared to 2013, was due to a decrease in exports and imports with Russia.

This reduction was not compensated by other countries. In 2013, the volume of cargo turnover with Russia was 38.3 billion dollars, in 2017 this figure amounted to 11 billion dollars. The fall was $75 \%$. With other countries foreign trade turnover has changed very insignificantly and in the general dynamics of the volume of turnover in billion dollars. decreased in 2017 by $33.8 \%$ compared to 2013 .

Accordingly, about one third of the capacity in logistics remained unoccupied, especially those who carried goods to Russia, Belarus and other CIS countries.

However, despite the reduction of the indicator of product turnover, the volume of transport services implemented in the country is increasing. Due to the growth of wholesale and retail trade turnover and industrial production in 2017, the market for transport services in Ukraine grew by $14 \%$, and for the first half of 2018 it was $16.8 \%$ compared to the same indicator in 2017 (Figure 5).

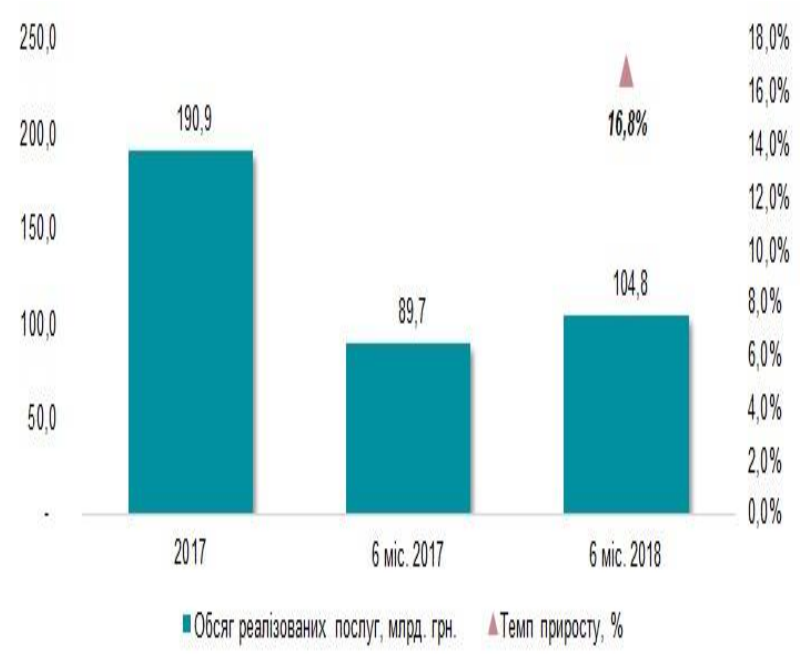

Fig. 5. Dynamics of volumes of transport services market in Ukraine in general in 2017 - 6 months. 2018 biennium, billion UAH.

Source: data of the State Statistics Service of Ukraine for 2017-2018.

If we consider the changes that took place in 20162017 in the structure of freight traffic, then it should be noted growth in the structural dynamics of goods transported by road transport. 
The reasons for such an increase are, first of all, the entry of large foreign companies into the market and the increase of investments in the development of road infrastructure, as well as a significant increase in tariffs for rail transport.

At the same time, we note a number of problems that have been disturbed in the past and continue to hinder the development of the transport industry to the full extent - low quality of transport infrastructure, obsolete rolling stock, significant impact of shadow transportation, politicization of governance and the process of updating road and railways in the country, high accident rate on roads.

The dynamics of market conditions freight road transport.

In the period of the crisis, the motor industry experienced the same losses as in the whole period of transport, and Ukraine's transport is at its most rapid pace, and the share of road transport in the volume of cargo transportation is increasing year by year, and in terms of freight turnover, by $15 \%$ in 2017 compared to 2013. (Table 1)

Table 1. The main indicators work of the transport in Ukraine.

\begin{tabular}{|c|c|c|c|c|c|c|}
\hline Year & \multicolumn{2}{|c|}{ All types of transport } & \multicolumn{2}{c|}{ Motor transport } & \multicolumn{2}{c|}{$\begin{array}{c}\text { Specific gravity in the total volume } \\
\text { of motor transport }\end{array}$} \\
\cline { 2 - 7 } & $\begin{array}{c}\text { Transported } \\
\text { cargoes } \\
\text { million tons. }\end{array}$ & $\begin{array}{c}\text { Cargo } \\
\text { turnover } \\
\text { billion tons }\end{array}$ & $\begin{array}{c}\text { Transported } \\
\text { cargoes } \\
\text { million tons. }\end{array}$ & $\begin{array}{c}\text { Cargo } \\
\text { turnover } \\
\text { billion tons }\end{array}$ & $\begin{array}{c}\text { Cargo } \\
\text { transported } \%\end{array}$ & $\begin{array}{c}\text { Cargo turnover } \\
\%\end{array}$ \\
\hline 2013 & 1802 & 393,3 & 1236 & 57,4 & 68,6 & 14,6 \\
\hline 2014 & 1623 & 353,6 & 1131 & 56,0 & 69,7 & 15,8 \\
\hline 2015 & 1474 & 334,7 & 1021 & 53,3 & 69,2 & 15,9 \\
\hline 2016 & 1543 & 344,2 & 1086 & 58,0 & 70,4 & 16,8 \\
\hline 2017 & 1582 & 364,2 & 1122 & 62,3 & 70,9 & 17,1 \\
\hline
\end{tabular}

Source: Transport and Communications of Ukraine 2017: Stat. save / ed. O.O. Karmazin. Kyiv. State Statistics Service of Ukraine, 2018. - P. 154 and own calculations.

The growth of the last indicator was facilitated by an increase in the average distance of road transport by one ton of goods (from $47 \mathrm{~km}$ in 2013 to 56 in 2017 [5, p. 57]).

Thus, according to the State Statistics Service of Ukraine, the volume of goods transported by road, amounted to 1.1 billion tons, or $102.9 \%$ of the volume of cargo in 2016. Starting from 2015, cargo turnover rates will increase by $107.4 \%$ in 2016 and $106.5 \%$ in 2017 (rice).

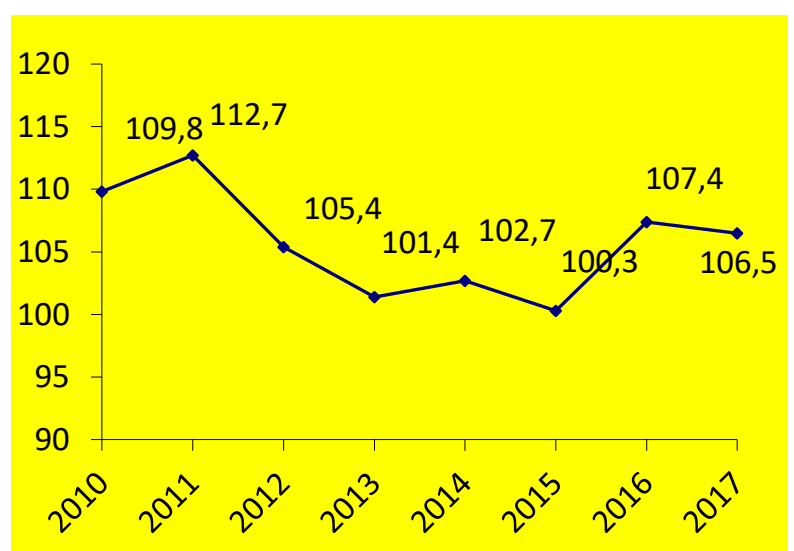

Fig. 6. Cargo turnover of road transport (in $\%$ to the previous year).

Source: Results of the motor transport operation in 2017. Express issue. Kyiv. State Statistics Service of Ukraine, 2018.

Among the economic sector, the largest share in the use of motor transport in Ukraine in 2016-2018 (Fig. 8) accounts for the extractive industry (18.6\%). Following this indicator are the food industry - 15.5\%), wood products - $13.2 \%$, and products of agriculture, forestry, fisheries and hunting -8.5 .

\section{Status and competitive environment within the industry.}

Analyzing the state and competitive environment in the market of motor transport services, it should be noted that it is highly competitive. It operates as large transport and logistics operators. as well as a significant number of small enterprises-carriers of goods, which in total is about 4 thousand business entities which in general corresponds to the world trends in the development of the automotive industry, according to which "the implementation of road freight transport by private operators in free markets - is the optimal scheme for the organization of such transportation" [1, c. 17].

Motor transport Freight is divided into two main types: domestic and international, performed by Ukrainian operators. Most carriers are interested in both directions, but some work on external routes does not allow the market situation or state of the vehicle fleet. Part of the operators - the heirs are still Soviet automobile bases, others, on the contrary, created in the last 5-7 years.

In the market of international road transportation there are 24 thousand cars, which are included in AsMAP, and another 7 thousand car carriers who are not members of this association. The total number of cars in the market of transport services exceeds 130 thousand. The major players in the market are Trans Service 1, AGS UKRAINE, Trans Logistics, Europe Trans Ltd, Orlan Trans Group, KVK Rapid and others.

Assessing the state of the motor transport industry V.V. Bilichenko, defines three clusters of investigated motor transport enterprises, which in his opinion are characterized by a certain degree of strategic development.

To cluster 1 ( $63.7 \%$ of the total number of trucking companies), there are small enterprises, which range from one to ten cars. They usually do not have the 
necessary material and technical support for the maintenance and repair of rolling stock.

To cluster 2 (25.2\% of the total number of trucking companies) there are automobile companies, which number from 10 to 50 cars. Their characteristic feature is the availability of a certain material and technical base for the maintenance and repair of rolling stock, and their management pays attention to how their business will develop.

The cluster $3(11.1 \%$ of the total number of aviation companies) includes automobile companies with more than 50 cars at their disposal. They have a good material and technical base for maintenance and repair of rolling stock, are industry leaders, are paying much attention to innovative processes in the management and implementation of new technologies in technology and overall improvement in the quality of transport work [2, p. 35-36].

The leading carriers, in addition to the fleet, have their own service centers, customs and warehouses. The main players in this market are as large manufacturers of Metinvest Holding LLC, Ukrnafta PAT, Kernel-Trade PAT and other such trading organizations, including retailer networks such as Silpo, Ashan, ATB-Market ", Metro Cash \& Carry Ukraine Ltd. and others.

Among the logistic operators in Ukraine, in recent years, they are developing and increasing their share in the market 3PL-operators (the segment of contractual logistics).

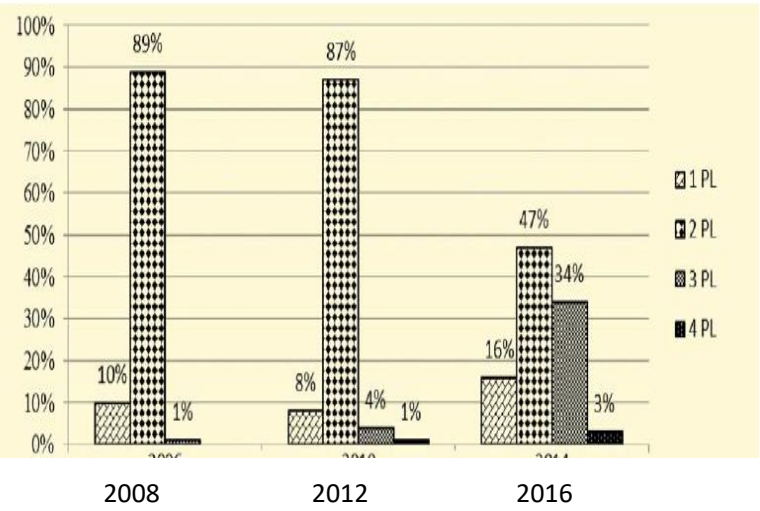

Fig. 7. The share of PL-operators in the structure of the logistic services market for 2008-2016.

Source: Analysis of logistic services market of Ukraine. https://pro-consulting.ua/ua/issledovanie-rynka/analizrynka-logistiki-ukrainy-2014-2015-gg.

For them, transportation is one of the profile functions, and $80 \%$ of the top 500 companies in the world use Fortune's list of services. [8] Among the Ukrainian companies that can be distinguished at this time - Business Group, ZAMMLER, Logistic Plus, UVK and NP Logistik.

The analysis of the results of economic activity of the subjects of the market of logistic services shows a low level of marginality and, accordingly, profitability of business. For most enterprises, the industry for 20142016 years was a loss, caused by an imperfect tariff policy in the area of service provision and the lack of transparency in the formation of costs for state transport companies.

Regarding the degree of openness of the market for logistics services in Ukraine, we determine that, despite positive trends from 2016 on increasing the volume of import and export of transport services, the share of transport services in the total volume of imports and exports of services has almost remained unchanged. The high share of transport services in the total volume of export of services shows the great importance of this sphere for the national economy.

The openness rate of the domestic market ranges from 10 to $19 \%$, which is evidence of a greater closedness of the market (for the open market, this ratio is more than $30 \%$ ). Of course, the value of these indicators depends significantly on the volume of international trade in Ukraine and the servicing of transit flows. The openness rate of the domestic market ranges from 10 to $19 \%$, which is evidence of a greater closedness of the market (for the open market, this ratio is more than $30 \%$ ). Of course, the value of these indicators depends significantly on the volume of international trade in Ukraine and the servicing of transit flows.

\section{Conclusions}

1. The analysis of the main factors influencing the level of competitiveness of economic entities in the market of transport services in Ukraine suggests that a favorable geographic location makes Ukraine an important transport hub connecting Europe, Asia and the Middle East. The road network of Ukraine covering the whole territory of the country makes it possible to deliver the cargo to any destination.

2. The analysis of foreign trade of the country shows its significant decrease in 2014-2016 as compared to the previous one (due to the global financial and economic crisis and the systemic economic and political crises in the country, and especially to Russian aggression).

3. However, despite the reduction of the indicator of product turnover, the volume of transport services implemented in the country is increasing. Due to the growth of wholesale and retail trade turnover and industrial production in 2017, the market for transport services in Ukraine grew by $14 \%$.

4. In the period of the crisis, the motor industry experienced the same losses as in the whole period of transport, and Ukraine's transport is at its most rapid pace, and the share of road transport in the volume of cargo transportation is increasing year by year, and in terms of freight turnover, by $15 \%$ in 2017 compared to 2013.

\section{References}

1.Amos P. (2004). Operational manual. The role of the state and the private sector in providing transport infrastructure and transport services. World Bank Group. Washington. 25. 
2. Bilichenko V. V. (2014). Background of the substantiation of strategic development of production systems of motor transport in Ukraine. Bulletin of the Zhytomyr State Technological University. №. 2. 33-43.

3.Zamlynsky V. A., Koval V. V., Kotlubay V. O. (2017). Status and prospects of development of export potential of the market of motor transport services. Economics and Society. No 9. 210-214.

4. Parubets O. M. (2018). Research of problems and prospects of development of export of transport services of Ukraine. Scientific notes of the National University of Ostroh Academy. Ostrog: NauOAO. No 9 (37). 21-24.

5. Transport and Communications of Ukraine 2017 (2018): Stat. save, ed. O.O. Karmazin. Kyiv. State Statistics Service of Ukraine.

6. Popovich P. V., Shevchuk O. S., Matviishin A. Y., Lototskaya V. M. (2016). Research of tendencies of development of the market of road haulage in modern conditions. Bulletin of the Zhytomyr State Technological University. № 2. 224-229.

7. Allen J., Browne M. T. (2012). Cherrett Investigating relationships between road freight transport, facility location, logistics management and urban form, Journal of Transport Geography, № 24, 45-57.

8. Top Global 3PLS. SJ Consulting Group. The journal of commerce URL: www.jindel.com.; Want a Better Supply Chain? Here Are 4 Reasons to Outsource Your Transportation Management. talkinglogistics.com.

\section{Список літератури}

1. Amos $P$. Operational manual. The role of the state and the private sector in providing transport infrastructure and transport services. World Bank Group. Washington 2004. 25 p.

2. Bilichenko $V$. $V$. Background of the substantiation of strategic development of production systems of motor transport in Ukraine. Bulletin of the Zhytomyr State Technological University. 2014. №. 2. P. 33-43.

3.Zamlynsky V. A., Koval V. V., Kotlubay V. O. Status and prospects of development of export potential of the market of motor transport services. Economics and Society. 2017. No. 9. S. 210-214.

4. Parubets $O$. M. Research of problems and prospects of development of export of transport services of Ukraine. Scientific notes of the National University of Ostroh Academy. Ostrog: NauOAO 2018 No. 9 (37). pp. 21-24.

5. Transport and Communications of Ukraine 2017: Cтат. save / ed. O.O. Karmazin. Kyiv. State Statistics Service of Ukraine, 2018.

6. Popovich P. V., Shevchuk O. S., Matviishin A. Y., Lototskaya V. M. Research of tendencies of development of the market of road haulage in modern conditions. Bulletin of the Zhytomyr State Technological University. 2016. № 2. P. 224-229.

7.Allen J., Browne M. T. Cherrett Investigating relationships between road freight transport, facility location, logistics management and urban form, Journal of Transport Geography 2012, № 24, 45-57.

8. Top Global 3PLS. SJ Consulting Group. The journal of commerce URL: www.jindel.com.; Want a
Better Supply Chain? Here Are 4 Reasons to Outsource Your Transportation Management // talkinglogistics.com

\section{ОСНОВНІ ФАКТОРИ ВПЛИВУ НА РИНОК ТРАНСПОРТНИХ ПОСЛУГ УКРАЇНИ О. М. Загурський, Б. С. Марченко}

Анотація. Стан ринку вантажоперевезень в Україні залежить від трьох основних чинників: зовнішньоторговельного обороту, валового внутрішнього продукту і виробництва. Коли всі ці показники зростають, логістика також розвивається, а разом 3 нею по висхідній лінії піднімається i транспорт.

В статті проведено аналітичне дослідження основних факторів впливу на рівень конкурентоспроможності господарюючих суб'єктів на ринку транспортних послуг в Україні.

Основними критеріями, що забезпечують сталий розвиток ринку автотранспортних послуг визначено: географічне положення; динаміку кон'юнктури галузевих товарних ринків; рівень попиту i пропозиції на ринку транспортних послуг; динаміку кон'юнктури ринку автотранспортних вантажних перевезень; стан і конкурентне середовище в середині галузі.

Результати проведеного аналітичного дослідження за 2014-2018 роки ринку транспортних послуг України засвідчують, що автотранспортна галузь зазнавши за період кризи таких же втрат як і загалом транспорт України найбільш швидкими темпами виходить із неї i питома вага автомобільного транспорту в обсягах перевезень вантажів з кожним роком зростає.

Ключові слова: автотранспорт, конкурентоспроможність, попит, пропозиція, ринок транспортних послуг.

\section{ОЦЕНКА РЫНКА ТРАНСПОРТНЫХ УСЛУГ УКРАИНЫ}

О. Н. Загурский, Б. С. Марченко

Аннотация. Формируя стратегию развития и функционирования отечественных отраслевых рынков необходимо поддерживать как суверенитет государства так и способствовать интеграции экономики страны в мировую хозяйственную систему. Особенно это относится к развитию экспорта транспортных услуг путем создания условий для привлечения транзитных грузопотоков на территорию Украины.

В статье рассмотрены методические подходы к факторам повышения конкурентоспособности хозяйствующих субъектов на рынке транспортных услуг в Украине. Среди основных віделені рыночные позиции хозяйствующих субъектов рынка (наличие потенциальных конкурентов, цены, качество) и уровень спроса на рынке (объем рынка, платежеспособность потребителей). Оценена степень монополизации, концентрации и конкуренции на рынке транспортных услуг.

Результаты исследования свидетельствуют о важном значении транспортной отрасли для 
экономики страны. Анализ рынка транспортных услуг показал, что он оптимально конкурентный, имеет низкую степень концентрации (коэффициента концентрации - 2,3\%) и власти крупнейших логистических компаний (индекс ННI $(0,8 \leq 1000)$, что характеризует его как совершенный с высоким уровнем конкуренции.

Ключевые слова: емкость, концентрация, конкурентоспособность, монополизация, рынок, транспортные услуги.

O. M. Zagursky ORCID 0000-0002-5407-8466.

B. S. Marchenko ORCID 0000-0002-8347-4813. 
